\title{
DEOFFSHORIZATION POLICY: CASE OF RUSSIAN COMPANIES
}

\author{
Anna Loukianova, ${ }^{1}$ Egor Nikulin, ${ }^{2}$ Alexander Kanivetc ${ }^{3}$
}

\begin{abstract}
This paper investigates the impact of deoffshorization on the market value of Russian companies. The methodology of event study was used. Three events were analyzed, including the announcement of intentions to leave offshores from several major companies and the introduction of anti-offshore legislation (December 2013 - March 2014). We have not revealed any mutually significant market response to the selected events, since some of the firms faced positive cumulative abnormal returns, while the others encountered negative ones. At the same time, an empirical study showed evidence of significant negative effect on the market value for several companies. It can be argued that the deoffshorization impact on companies depends to a large extent on the offshore structure they use. Companies that are significantly exposed to deoffshorization need to adjust their strategy in order to counter potential negative consequences of this process.
\end{abstract}

JEL Classification Numbers: M10, M40, M41, M48; DOI: http://dx.doi.org/10.12955/cbup.v5.939

Keywords: offshore, deoffshorization, deoffshorization policy, company valuation

\section{Introduction}

Offshores or as they are alternatively called tax havens, play an important role in today's worldwide economy. It is presumed that companies, as well as individuals, use them in order to lower their taxable income. Such a phenomenon is known as tax avoidance. As a result, governments receive less taxes than expected. As Zucman (2015) points out, wealthy individuals hide an estimated \$7.6 trillion in tax havens, that leads to an estimated annual loss in government tax revenue of $\$ 190$ billion worldwide. Not surprisingly, state authorities of different countries have started to elaborate specific instruments in order to hinder the extent of offshorization. For example, General Anti-Avoidance Rules (GAAR) were enacted in the UK in 2012; financial transactions taxes have been developed in several European countries in 2012-2013, etc. Russia made no exception in this regard. The address of the President of the Russian Federation Vladimir Putin to the Federal Assembly of Russia on December 12 ${ }^{\text {th }}, 2013$ ushered in the initial stage of state deoffshorization policy in the country.

Deoffshorization generally brings negative consequences for companies, since they lose benefits of offshores they used to enjoy and in addition to that are expected to incur a particular amount of costs. These economic effects can be classified as follows (Desai and Dharmapala, 2004). Firstly, companies lose the tax benefits granted by offshore zones. Secondly, they may incur significant nontax costs because of the necessity to restructure their operations. Finally, companies often have to relocate their business to a less attractive regulatory environment and consequently, take more risks.

The goal of the current paper is to assess and explain the effect of the announcement of the state deoffshorization policy, triggered by the Russian government in late 2013, as well as the consequent corporate decisions to deoffshorize on the market value of Russian companies. Such a task has certain practical implications. The change in share price at the time of announcement would reflect how investors estimate the net present value of all the deoffshorization effects described above. If the change is negative, then a company should develop a set of measures in order to counter the detrimental consequences of deoffshorization. In other words, a company should develop the strategy of how to switch from offshore jurisdiction to the national one as cheaply as possible and to remain competitive at the same time.

\section{Theoretical background}

The term "offshore," as well as some other terms implying the same meaning (i.e. tax havens), are frequently used nowadays in academic as well as professional publications. In a nutshell, offshores are considered to be countries (or strictly speaking, legal units) that provide favorable economic conditions for businesses. One of the first attempts at classifying and analyzing offshores and offshore operations was provided in the reports conducted by several well-known international organizations in late 1990s - early 2000s. (see, e.g., OECD, 1998; IMF, 2000; FATF, 2000). For example, the report of the International Monetary Fund (IMF) distinguished between offshore finance and offshore financial center

\footnotetext{
${ }^{1}$ Graduate School of Management, Saint Petersburg University, anna.loukianova@gsom.pu.ru

${ }^{2}$ Graduate School of Management, Saint Petersburg University, nikulin@gsom.pu.ru

${ }^{3}$ Graduate School of Management, Saint Petersburg University, aleksandr.kanivetc@ gmail.com
} 
(IMF, 2000). The term "offshore finance" was used in this report in a very broad meaning, encompassing all financial services provided to non-residents. Hence, the concept of offshore financial center that was also used in this report appeared to be somewhat vague, since it covered every financial center that provided offshore services.

Over the course of years, the concept of offshores has become more specific. For example, Kheyfets (2013) outlined the main criteria that needed to be met by legal units in order to be considered offshores:

1. Opportunities for significant tax and other expenses mitigation;

2. A favorable legal environment for establishing and running a business. This usually includes simplified administrative and financial control;

3. The possibility of anonymous financial transactions and concealing the final beneficiaries of such operations.

In other words, the concept of offshores or tax havens started to be used primarily with reference to the tax avoidance phenomenon. A lot of studies show that companies that have part of their operations in offshores are able to decrease their overall tax burden (Lee, 2017). Such an effect can be detrimental to governments all over the world, since they get less revenue than expected. Taking this into consideration, it seems quite feasible that a number of deoffshorization measures were initiated at the national as well as international levels.

The prominent wave of deoffshorization measures in the world was initiated in 2008 and can be attributed to the beginning of global economic crisis. One of the first steps was the classification of different offshore zones (under the three-coloured scale) by the Organisation for Economic Co-operation and Development (OECD, 2009). Subsequent measures included the enactment of the Foreign Account Tax Compliance Act (FATCA) in the USA in 2010; the establishment of an EU-wide tax avoidance countering system (Eurofics) in 2010, etc...

Deoffshorization policy in Russia

The issue of offshores for Russia was and remains significant. Kheyfets (2010) argued that the Russian economy was offshorized to a large extent, since many Russian corporations were in fact controlled by holdings incorporated in offshore zones. Thus, the need for deoffshorization was feasible. According to (Glaz'ev, 2014), the purpose of deoffshorization in Russia could be treated in two ways: firstly, as the decrease of quantity of offshores used by Russian companies, and secondly, as the decrease of the flow of money and goods that come from Russia and into Russia through offshores.

The event that in our opinion has triggered the development of deoffshorization measures in Russia was the address of President Vladimir Putin to the Federal Assembly of the country on December 12 $2^{\text {th }}, 2013$. In this address, he pointed out the existence of a big amount of losses to the federal budget caused by an excessive degree of offshorization of the Russian economy. He touched on the same issue in his address of the previous year however, according to his opinion, the results were hardly visible as of 2013. That's why he suggested a set of measures targeted at deoffshorization. For instance, he proposed to cut off the Russian companies registered abroad from governmental support measures and to forbid them to participate in governmental purchase tenders (NewsKremlin.ru, 2013). He also emphasized the necessity for increasing the transparency of the Russian economy.

As a follow-up event, several Russian companies (RusHydro, UC RUSAL, Sovcomflot and KAMAZ) announced their intentions to deoffshorize on December $18^{\text {th }}, 2013$ (Infox.ru, 2013). RUSAL presssecretary Olga Sanarova declared that the company has already developed a plan of reorganizing financial and trade operations to shift to Russian jurisdiction. CEO of KAMAZ Sergey Kogogin announced that KAMAZ shareholders also supported the idea of restructuring. RusHydro planned to finish the elimination of its Cyprus subsidiaries by the end of 2014, according to vice-chairman of the company George Rizhinashvili.

As for the initial legislative measures of the deoffshorization policy, the draft of Controlled Foreign Entities Bill was proposed by the Ministry of Finance on March $18^{\text {th }}, 2014$. The importance of this bill is that it introduced the notion of a controlled foreign company. It is a company that simultaneously fulfills the following criteria (abridged):

1. It is not considered a tax resident of Russian Federation. 
2. It is a tax resident of a country (jurisdiction), which is on the list of low-tax zones approved by Russian Ministry of Finance.

3. It is controlled by companies or individuals, who are tax residents of the Russian Federation.

4. Company shares are not publicly traded on stock exchanges approved by the Russian Ministry of Finance.

The Bill also introduced the concept of control. According to the document, a controlling company or individual was considered to be the one who had implicit or explicit ownership of more than $10 \%$ of the controlled foreign company. The main practical importance of the Bill was that it required controlled companies to report its profits in accordance with the Russian Tax Code. This initiative, without a doubt, targeted offshore subsidiaries of Russian companies used for profit accumulation and other aggressive tax avoidance measures.

Although the anti-offshore legislation in Russia continued to develop since then, in the current paper we focus only on the initial measures and events targeted to ensure deoffshorization in Russia (Loukianova, Kanivetc, 2014). In other words, we aim to identify the market's reaction to the very first steps in the direction of deoffshorization in Russia. Such an approach would enable us to single out companies that are more exposed to the potential negative consequences of deoffshorization. We believe that the strategy of these companies should contain specific instruments tailored to counter these negative factors in order to maintain their enterprise value.

\section{Methodology}

For our research, we have chosen nine large Russian companies that, according to open sources of information, were involved in offshore schemes. Another criterion was the availability of free-trading stock. The final sample comprised the following companies: JSC Rushydro, JSC KAMAZ, JSC MTS, JSC NLMK, JSC Nornickel, JSC Gazprom, JSC Rosneft, Evraz Plc and UC RUSAL Plc.

An event study methodology was used. There were two types of events: reorganization announcements by the companies' officials and the governmental bodies' actions. The following three major deoffshorization-related events were selected for the study:

1. December 12 $2^{\text {th }}, 2013:$ V.V. Putin's address to the Federal Assembly of the Russian Federation

2. December $18^{\text {th }}, 2013$ : The declaration of intentions to deoffshorize by RusHydro, UC RUSAL, KAMAZ, etc.

3. March $18^{\text {th }}$, 2014: The introduction of the Controlled foreign companies (CFC) law by the Ministry of Finance.

One-day, two-day (from day 0 to day +1 ) and five-day (from day -2 to day +2 ) cumulative abnormal returns (CARs) around the announcement date (which is denoted day 0) were examined. We also introduce a 5-days gap between the two intervals to exclude any preliminary effects of the event, which could possibly influence the stock behavior in advance to the event itself and add bias to the estimation window. We introduce the following notation: $T_{0}$ is the first day of the estimation period, $T_{1}=T_{0}+249$ is the last day of the estimation period, $\mathrm{T}_{2}=\mathrm{T}_{1}+5$ is the first day of the event window, $\mathrm{T}_{3}$ is the last day of the event window (see Figure 1).

Figure 1: Timeline of empirical study


Simple daily returns are constructed using the stock market data for the selected companies' share prices in the period outlined above. First, usual daily returns are calculated as follows:

$$
R_{i, t}=\frac{P_{i, t}}{P_{i, t-1}}-1,
$$

where $P_{i, t}$ is the share price of $i$ th company on day $t, i=1, \ldots, 9$, a number of companies in selection (here and further, unless noted otherwise).

Cumulative returns were computed according to the following formulae:

$$
\begin{gathered}
1 \text { - day } C A R_{i, t}=A R_{i, t}=R_{i, t}-E R_{i, t} \\
2-\text { day } C A R_{i, t}=\sum_{t=0}^{t=1} A R_{i, t} \\
5-\text { day } C A R_{i, t}=\sum_{t=-2}^{t=2} A R_{i, t} .
\end{gathered}
$$

Then the expected returns for the selected companies were constructed. Though Desai and Hines (2002) and Cloyd et al. (2003) propose using simple market daily returns as a proxy of expected return, we aimed to increase the precision of the results and therefore used the CAPM model:

$$
E R_{i, t}=r_{f}+\beta\left(R_{m, t}-r_{f}\right),
$$

where $E R_{i, t}$ is the expected return for the company $i, r_{f}$ is the risk-free rate of return, $\beta$ is the betacoefficient, and $R_{m, t}$ is the market return.

$R_{m, t}$ was taken as the market portfolio return according to the stock exchange residence of the company. For companies traded at the Moscow Stock exchange the proxy for market return was the MICEX index portfolio behaviour. For Evraz, which is traded at the London Stock exchange, the proxy was return on FTSE100, and for RUSAL (traded at Hong Kong Stock exchange) market return was taken as return on

\begin{tabular}{|c|c|c|c|c|c|c|c|c|c|}
\hline Company & RusHydro & Kamaz & MTS & Rosneft & NorNickel & Gazprom & NLMK & Evraz & Rusal \\
\hline Beta 12th Dec & 1,10 & 1,18 & 0,70 & 0,76 & 1,02 & 1,26 & 1,32 & 1,58 & 1,23 \\
\hline Beta 18th Dec & 1,09 & 1,17 & 0,71 & 0,75 & 0,99 & 1,27 & 1,32 & 1,59 & 1,24 \\
\hline Beta 18th Mar & 1,09 & 1,17 & 0,75 & 0,81 & 1,02 & 1,27 & 1,32 & 1,61 & 1,24 \\
\hline
\end{tabular}
the Hang Seng index.

To obtain the quantitative form of equation (3), a regression of $R_{i, t}$ on $R_{m, t}$ was carried out for each company across the estimation period window (250 trading days) preceding the event date. The results are shown in Table 1.

Finally, the possible biases from external events are taken into consideration by taking away the strings of data related to dividends and earnings announcements (based on companies' press releases and business news, including financial calendars). Approximately 5-10 dates were excluded for each company from the estimation window.

Given the potential negative consequences to deoffshorization we expect that the market value of companies will react negatively to the deoffshorization announcements.

\section{Results}

Firstly, cumulative abnormal returns of companies were constructed for each event date and compared with each other to reveal, if present, similar direction of returns on stocks movements against the market portfolio. Secondly, a mutual significance of CARs was estimated based on the GRANK statistic.

Figure 2 shows the distribution of CARs by companies selected for the study for the $12^{\text {th }}, 18^{\text {th }}$ and $19^{\text {th }}$ of December.

It was reasonable to expect mutual negative reactions at least for the majority of companies. However, no correlated behavior of the companies' share prices against the market is observed, as some of the firms face positive CARs, while the others face negative ones.

At the same time, CARs are correlated within most companies for consequent days. One of the exceptions would be KAMAZ. We can see that this company has at first reacted positively to the announcement, but afterward had strong negative reaction to the events. 


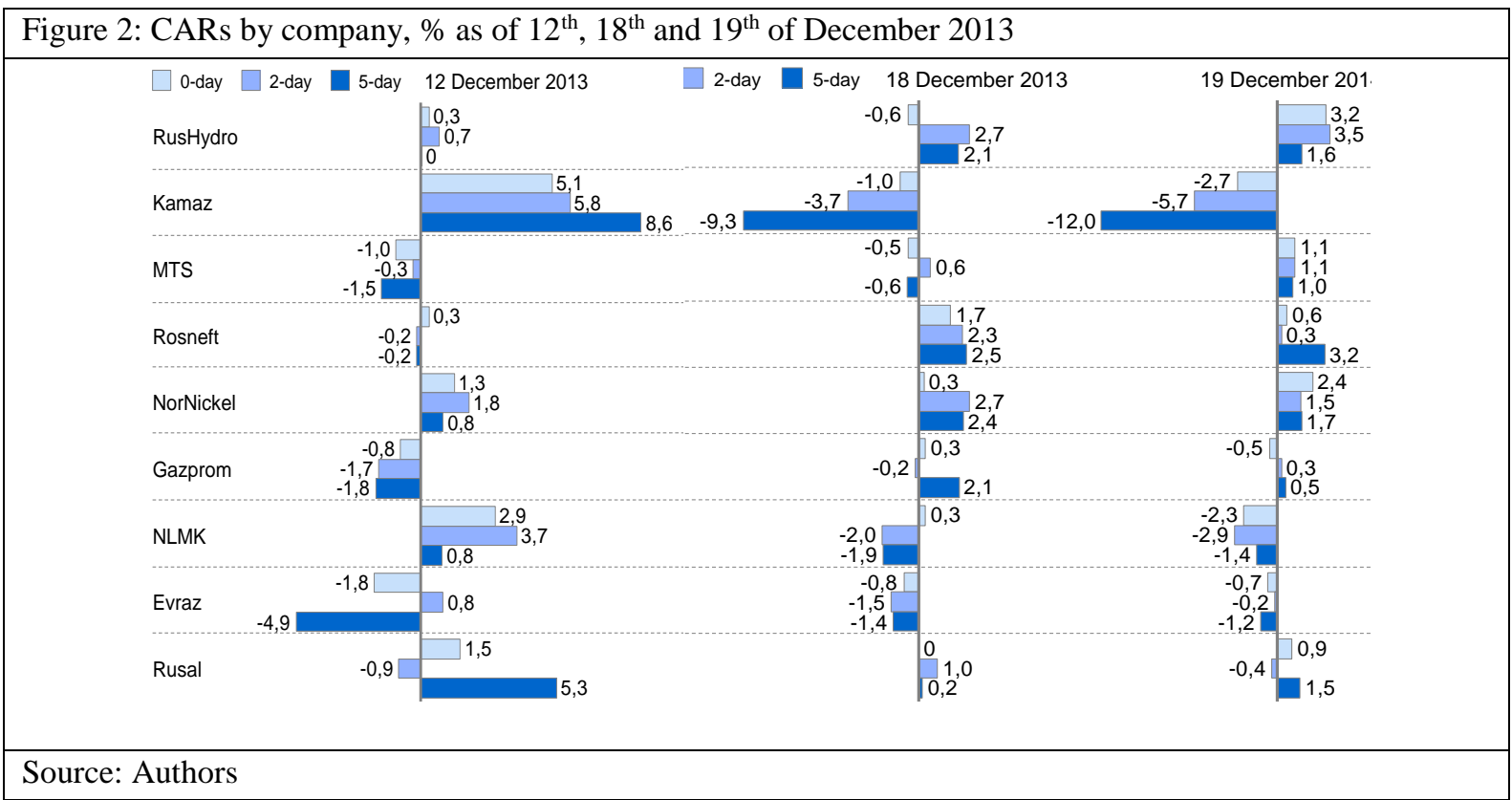

Figure 3 contains the CARs of preselected companies for the $18^{\text {th }}$ and $19^{\text {th }}$ of March 2014, which are the days consequent to the introduction of the initial version of the CFC law by the Russian Ministry of Finance. Here it would be reasonable to expect mutual negative behavior of the companies' abnormal returns, with possible little negative change for KAMAZ, as the market may have already incorporated the expected loss into its share price in December. However, here we do not observe such effect, as only Norilsk Nickel and NLMK demonstrate negative abnormal returns over the selected timeframe. At the same time, Evraz and RUSAL have outstanding positive returns in comparison to the market portfolio.

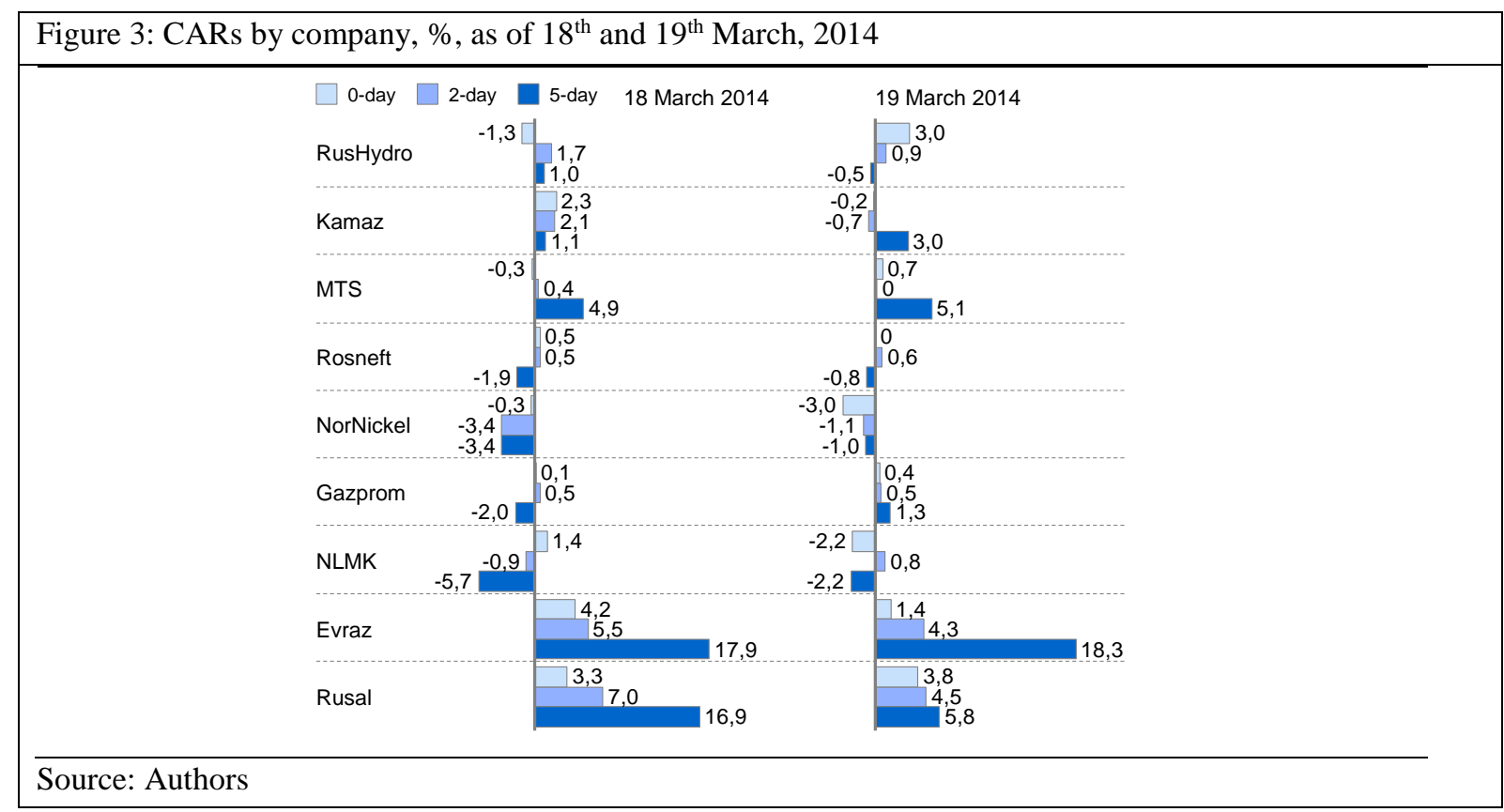

So far, the comparison of absolute values of cumulative abnormal returns does not allow for witnessing the presence of mutual negative (or positive) market responses to the deoffshorization events. To assess this statement statistically, we proceed to estimate the mutual t-statistics by using the GRANK approach. Unsurprisingly to the observations in Figures 2 and 3, but contradictive to the expectations highlighted in the theoretical explanation of deoffshorization implications for the companies, we see no mutually significant market response to the selected events (see Figure 4).

Furthermore, the average behavior across the portfolio is positive (though insignificant) for all events. This effect can be attributed to the fact that not all companies' values are subject to deoffshorization 
announcements and legislations introduced. Thus, positive or no market reaction for some companies blurs the overall picture for the portfolio.

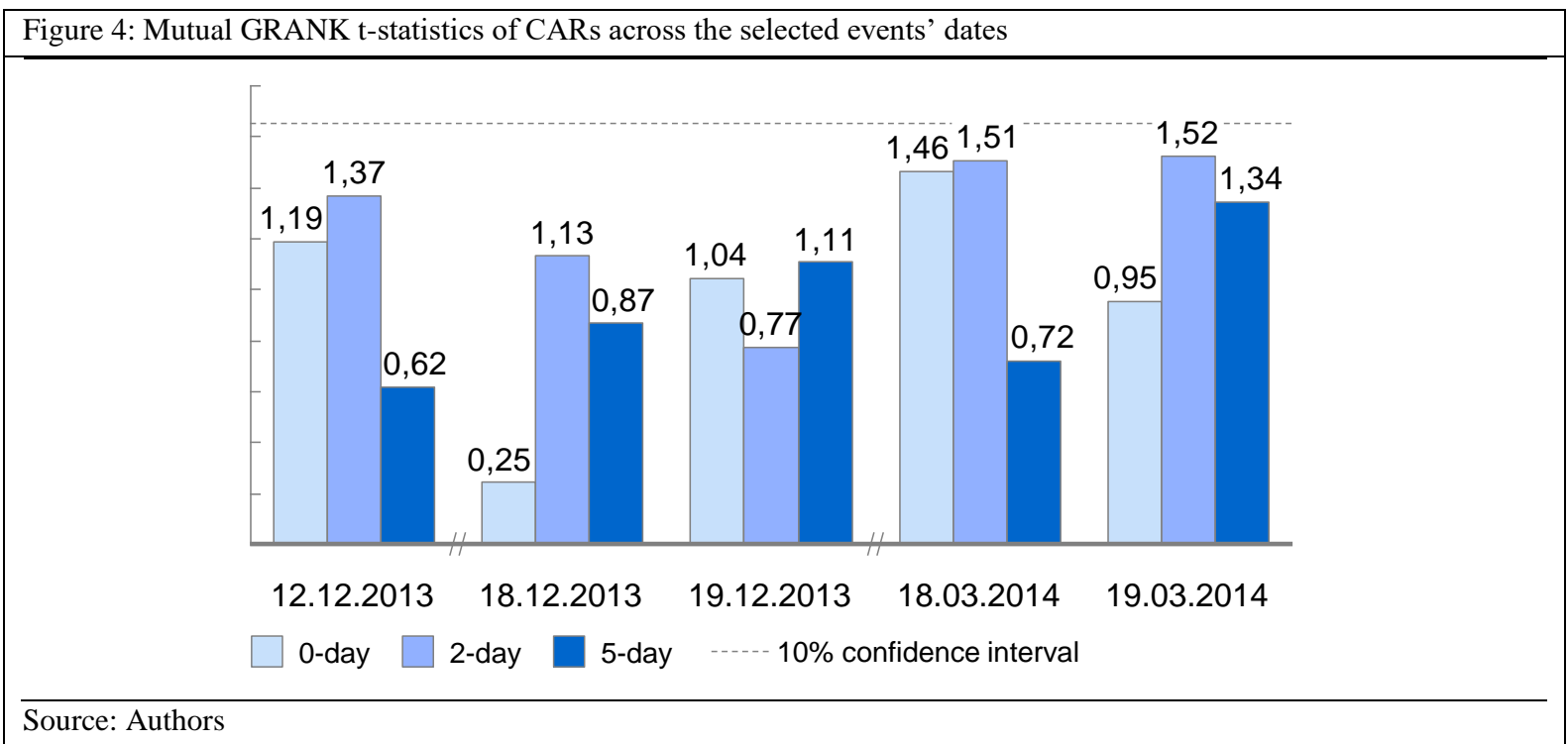

We believe that such a difference in results between companies can be attributed to the fact that they use different offshore schemes. That is why they are to a different extent sensitive to the state's deoffshorization initiatives. This can be shown with the example of two companies: UC RUSAL and JSC KAMAZ.

UC RUSAL is almost fully owned through offshore-registered holdings and companies (RUSAL, 2014). Such a structure makes this company less sensitive to the CFC law. This fact may cause the absence of negative market reaction to the enactment of the initial version of this law on March $18^{\text {th }}$ and $19^{\text {th }}$. If a company strives to maintain its offshore advantages, it needs to keep the existing offshore structure.

JSC KAMAZ possesses another ownership structure. Some of its owners are registered in Russia, while the other are registered in Cyprus (KAMAZ 2014; Lyapunov et al, 2014). Such a structure renders this company exposed to the deoffshorization policy of Russia, since the owners of this company face the issue of increased taxation. In order to restrain these negative effects, they should consider the following options. Firstly, they can leave the Russian tax residence. However, this option is not very likely, since a significant share of ownership of JSC KAMAZ belongs to the state. Another option could be the dispersion of the ownership of the Russian business across several offshore companies with a small stake in each.

\section{Conclusion}

The results of our study revealed that there was no universal market reaction to the three events that characterized the initial stage of the state deoffshorization policy in Russia: V.V. Putin's address to the Federal Assembly of Russian Federation (December 12 $2^{\text {th }}, 2013$ ); the declaration of intentions to deoffshorize by several large Russian companies (December 18 ${ }^{\text {th }}, 2013$ ); the introduction of the Controlled Foreign companies (CFC) law by the Ministry of Finance (March 18 ${ }^{\text {th }}$, 2014). Some companies faced positive cumulative abnormal returns, while others had negative ones. The difference in results can be attributed to the fact that companies used different offshore schemes that make them more or less sensitive to the state's deoffshorization measures. The implications of the empirical analysis are that companies should analyze whether their structure is dependent on the state's deoffshorization policy and if it is, to develop a set of measures in order to mitigate these negative factors.

We believe that the findings of our research are not limited to the companies considered in our sample. Indeed, they can be applied to different companies in Russia that are engaged in offshore operations and serve a useful tool for the development of strategies against the potential negative consequences of deoffshorization.

\section{References}

Cloyd, C., Mills, B., Lillian, F., \& Weaver, C.D. (2003). Firm Valuation Effects of the Expatriation of U.S. Corporations to Tax-Haven Countries. Journal of the American Taxation Association 25, Supplement, 87-109. 
Desai, M. \& Dharmapala, D. (2004). Corporate Tax Avoidance and High Powered Incentives. NBER Working Paper, no.10471 (May). Retrieved from www.nber.org/papers/w10471

Desai, M.A. \& Hines, J.R., Jr. (2002, June). Expectations and Expatriations: Tracing the Causes and Consequences of Corporate Inversions. NBER Working Paper, no. 9057. Retrieved from http://www.bus.umich.edu/otpr/wp2002-4.pdf FATF. (2000). Report on Non-Cooperative Countries and Territories. Retrieved from www.fatfgafi.org/dataoecd/57/22/33921735.pdf

Glaz'ev S.Yu. (2014). Deoffshorization of the Russian economy. The ways and measures. The White Paper. Retrieved from http://dynacon.ru/content/articles/2701 [In Russian]

IMF. (2000). Offshore Financial Centers. IMF Background Paper. Retrieved from www.imf.org/external/np/mae/oshore/2000/eng/back.htm

Infox.ru. (2013). KAMAZ, RusHydro and RUSAL announced deoffshorization. [In Russian]. Infox.ru, December 18. Retrieved from http://www.infox.ru/business/company/2013/12/18/_Kamaz Rusgidr.phtml

KAMAZ. (2014). List of affiliates. Retrieved from http://kamaz.net/ru/investor/stock/

Kheyfets, B. (2010). Offshorization Non Stop. Rossiiskaya Federatsiya Segodnya, 10, 41-42.

Kheyfets, B. (2013). Economy deoffshorization: international experience and Russian specifics. [In Russian]. Voprosy Ekonomiki, 7, 27-48.

Lee, N. (2017). Can Territorial Tax Compliance Systems Reduce the Tax Avoidance of Firms with Operations in Tax Havens? Emerging Markets Finance \& Trade, 53, 968-985.

Lokianova, A. \& Kanivetc, A. (2014). Deoffshorization implications for Russian companies management. In Proceedings of International Conference "GSOM Emerging Markets Conference: Business and Government Perspectives", 279-288.

Lyapunov, M., Tyurin, A., \& Yarhamov, I. (2014). Kamaz leaves offshores. Kazanfirst.ru. Retrieved from http://kazanfirst.ru/feed/16420

NewsKremlin.ru. (2013). Message of President to the Federal Assembly. [In Russian]. Retrieved from http://news.kremlin.ru/transcripts/19825

OECD. (1998). Harmful Tax Competition. An Emerging Global Issue. Paris: OECD Publications. Retrieved from http://www.oecd.org/tax/transparency/44430243.pdf

OECD. (2009). A progress report on the jurisdictions surveyed by the OECD Global Forum in implementing the internationally agreed tax standard. Progress made as at 2nd April 2009. http://www.oecd.org/dataoecd/38/14/42497950.pdf RUSAL. (2014). Ownership structure. [In Russian]. Retrieved from http://www.rusal.ru/investors/to_shareholders/structure.aspx

Zucman, G. (2015). The Hidden Wealth of Nations: The Scouge of Tax Havens. University of Chicago Press, Chicago, IL. 